This item was submitted to Loughborough's Research Repository by the author.

Items in Figshare are protected by copyright, with all rights reserved, unless otherwise indicated.

\title{
The potential of PV installations in SIDS - an example in the island of
} \section{Barbados}

PLEASE CITE THE PUBLISHED VERSION

http://www.emeraldinsight.com/journals.htm?issn=1477-7835

PUBLISHER

(C) Emerald

VERSION

AM (Accepted Manuscript)

LICENCE

CC BY-NC-ND 4.0

REPOSITORY RECORD

Rogers, Thomas, Ksenia Chmutina, and L. Leo Moseley. 2019. "The Potential of PV Installations in SIDS - an Example in the Island of Barbados". figshare. https://hdl.handle.net/2134/10257. 
This item was submitted to Loughborough's Institutional Repository (https://dspace.lboro.ac.uk/) by the author and is made available under the following Creative Commons Licence conditions.

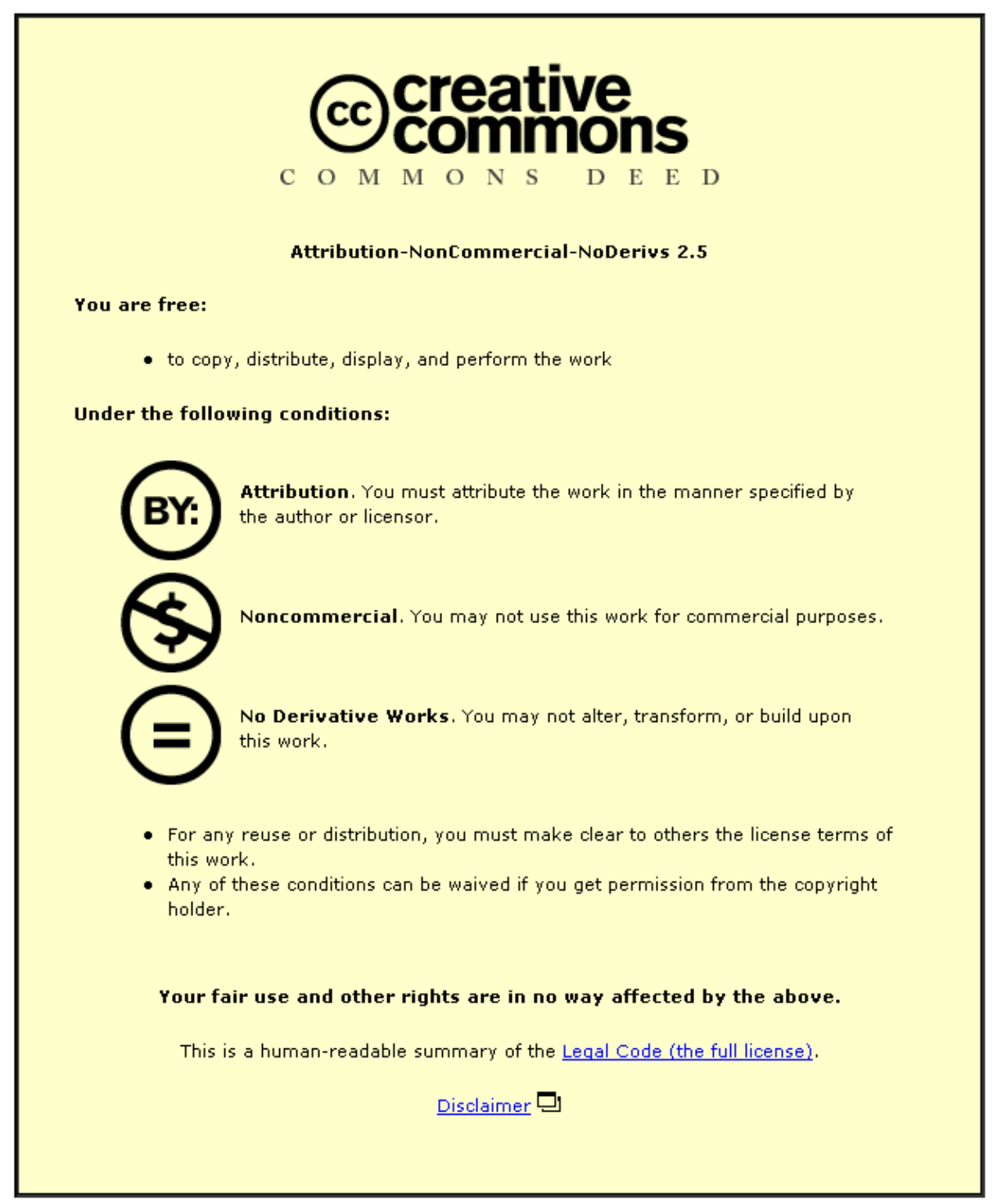

For the full text of this licence, please go to: http://creativecommons.org/licenses/by-nc-nd/2.5/ 


\title{
The potential of PV installations in SIDS - an example in the island of Barbados
}

\author{
Thomas Rogers ${ }^{1}$, Ksenia Chmutina $^{2}$, L. Leo Moseley ${ }^{1}$ \\ ${ }^{1}$ University of the West Indies, Cave Hill Campus, Barbados \\ ${ }^{2}$ Department of Civil and Building Engineering, University of Loughborough, UK. \\ Paper submitted $5^{\text {th }}$ December 2010 \\ Paper revised $12^{\text {th }}$ October 2011 \\ Article type: Case study
}

\begin{abstract}
:
Purpose - This paper reviews the current status of photovoltaics on the island of Barbados, including experiences to date, and discusses the future directions with a view to sharing the experience gained with other SIDS.

Design/Methodology/Approach - As with many Small Island Developing States (SIDS) Barbados is heavily reliant upon fossil fuels to meet their electricity generation needs (currently $98 \%$ of total electricity generation). The paper outlines how solar PV sits within the existing energy structure for the island of Barbados and reflects on the experience gained from the success of its solar thermal hot water heating industry.
\end{abstract}

Findings - This paper estimates the installed capacity of photovoltaic solar systems on Barbados was estimated to be around $200 \mathrm{kWp}$ in $2010(0.18 \%$ of the average electricity demand, not including the load factor of the PV systems).

Practical implications - With an average daily solar radiation of $5.7 \mathrm{kWh} / \mathrm{m}^{2}$, the potential of the resource is clear to see, with solar PV being capable of substantially contributing to the island's energy mix and saving valuable foreign exchange.

Originality/value - Concerning the increasing role of solar PV in the energy mix for Barbados, substantial barriers are still observed. The paper has tried to identify these barriers and has provided a detailed overview of the energy sector and solar thermal success in Barbados.

Keywords: Photovoltaic systems, Barbados, SIDS.

\section{Introduction}

Small island states can be very diverse geographically, as well as culturally; however, most of them share similar environmental and economic vulnerabilities and challenges for sustainable development (Barbados National Energy Policy DRAFT, 2007). Most small islands are dependent on imported energy sources, mainly in the form of fossil fuels, see Figure 1. These imports cover energy needs for transportation and electricity production, and their dependency 
on these imports to maintain levels of economic energy intensity make them more vulnerable than most mainland countries to events beyond their control, such as global energy price rises. Their small size and isolated locations contribute to high energy and transportation costs, diseconomies of scale, and unfavourable power plant management options; these being the main reasons for the expensive energy prices when compared with mainland countries. This makes the application of sustainable energy technologies not an option but a must for small islands, especially as global energy prices continue to rise (UN Economic and Social, 2006). To date, many SIDS do not have a high penetration of renewable energy, even though high imported energy prices create a good market opportunity. Moreover, most of the small islands have good climatic conditions for renewable energy technology development (especially sun and wind and in some cases geothermal and marine resources). There are still only a few islands around the world with a significant utilisation of renewable energy. As Patrizio Civili, the Assistant Secretary-General for Policy Coordination and Inter-Agency Affairs, stated, 'the dependence of Small Island Developing States on imported fuels for transportation and power generation remains a significant challenge to development' (UN Economic and Social, 2006). Collectively, small island states spend more than US\$90 million per day on more than 900,000 barrels of oil. If this single sum of money were invested in renewable energy generation, $72 \mathrm{MW}$ of wind capacity or $11 \mathrm{MW}$ of solar capacity could be installed (Garcia and Meisen, 2008).

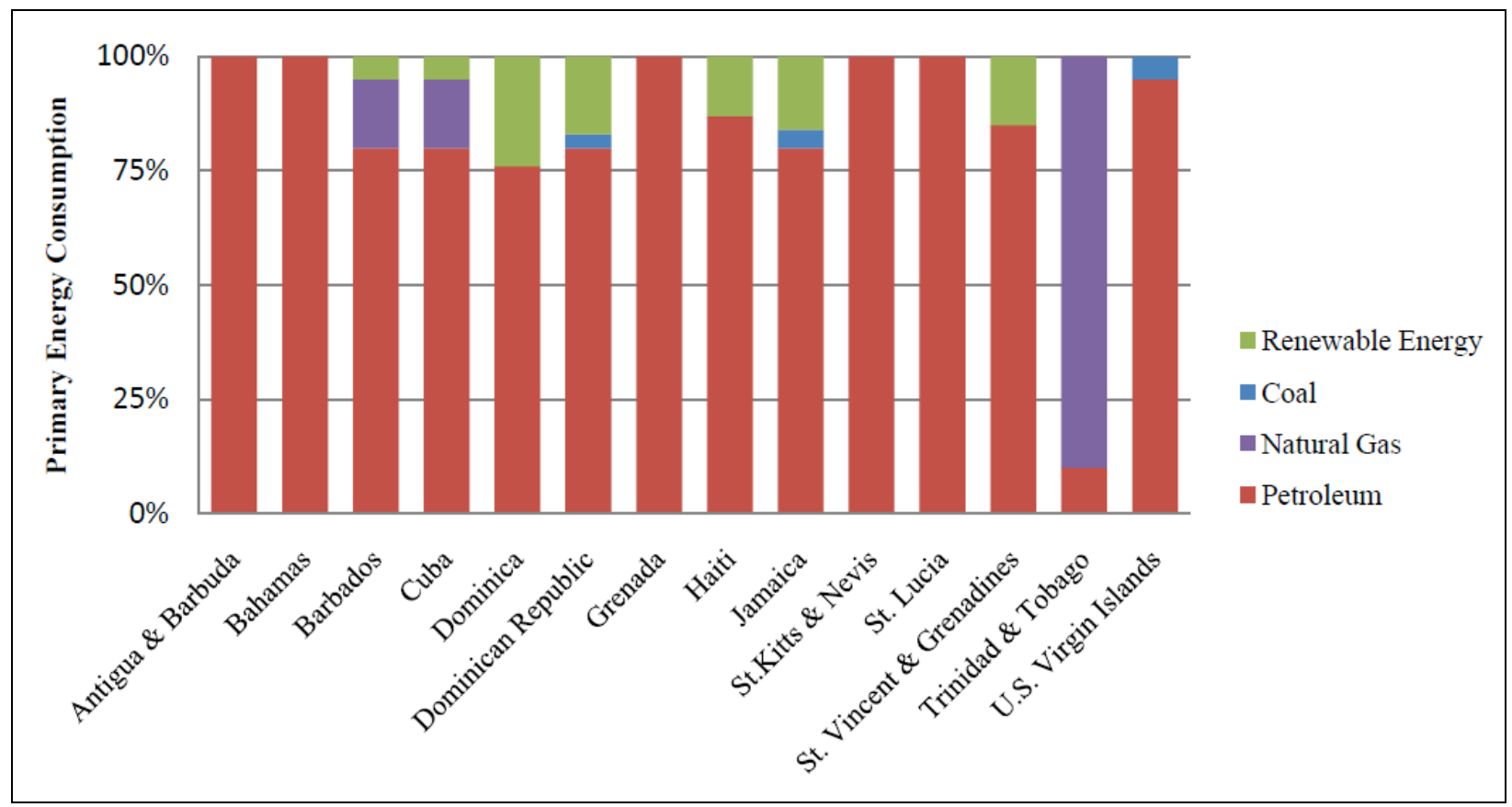

Figure 1. Energy consumption pattern of Caribbean SIDS [EIA, 2010].

\section{Barbados Solar Thermal Success}

Barbados, the most easterly of the islands in the Caribbean, is approximately $430 \mathrm{~km}^{2}$ in area $(23 \mathrm{~km}$ by $34 \mathrm{~km})$, see Figure 2 . It has a population of around 280,000 people (excluding the 1.1 million tourists who visit the island each year) and is ranked 37th in the UNDP's Human Development Index (HDI). It is therefore classed as having a 'very high human development' (UNDP Human Development Report, 2010). The fact that SIDS includes islands from all four rankings of the HDI makes direct comparison of renewable energy progress difficult. 
The average daily insolation in Barbados is $5.7 \mathrm{kWh} / \mathrm{m}^{2}$ (Moseley and Headley, 1998). For comparison, in Germany and Japan, countries with some of the highest installed PV capacity, the sunniest places in these two countries have an average daily insolation of $3.35 \mathrm{kWh} / \mathrm{m}^{2}$ and 4.43 $\mathrm{kWh} / \mathrm{m}^{2}$ respectively. This prime resource in Barbados has yet to be fully utilised by solar photovoltaic technologies but the success of simpler and cheaper solar thermal systems has been well documented (Headley, 1998) (Langniß and Ince, 2004) (Science \& Technology). Barbados's solar hot water system manufacturers were established in the 1970s and it is estimated that around US\$10 million is now saved each year (the alternative being electric immersion heaters or gas powered water heaters) (Langniß and Ince, 2004). Although the initial stimulus for the technology was a large part due to the 1970 s oil crisis, the industry benefited from government support in the form of fiscal incentives that allowed consumers tax relief and manufacturers to benefit from import preferences and tax holidays. Also key was the healthy competition between a number of manufacturers/installers (Solar Dynamics, Sun Power and later on, AquaSol). Currently two out of every five homes on the island use solar hot water heating (45,000 systems), as well as many businesses and most hotels.

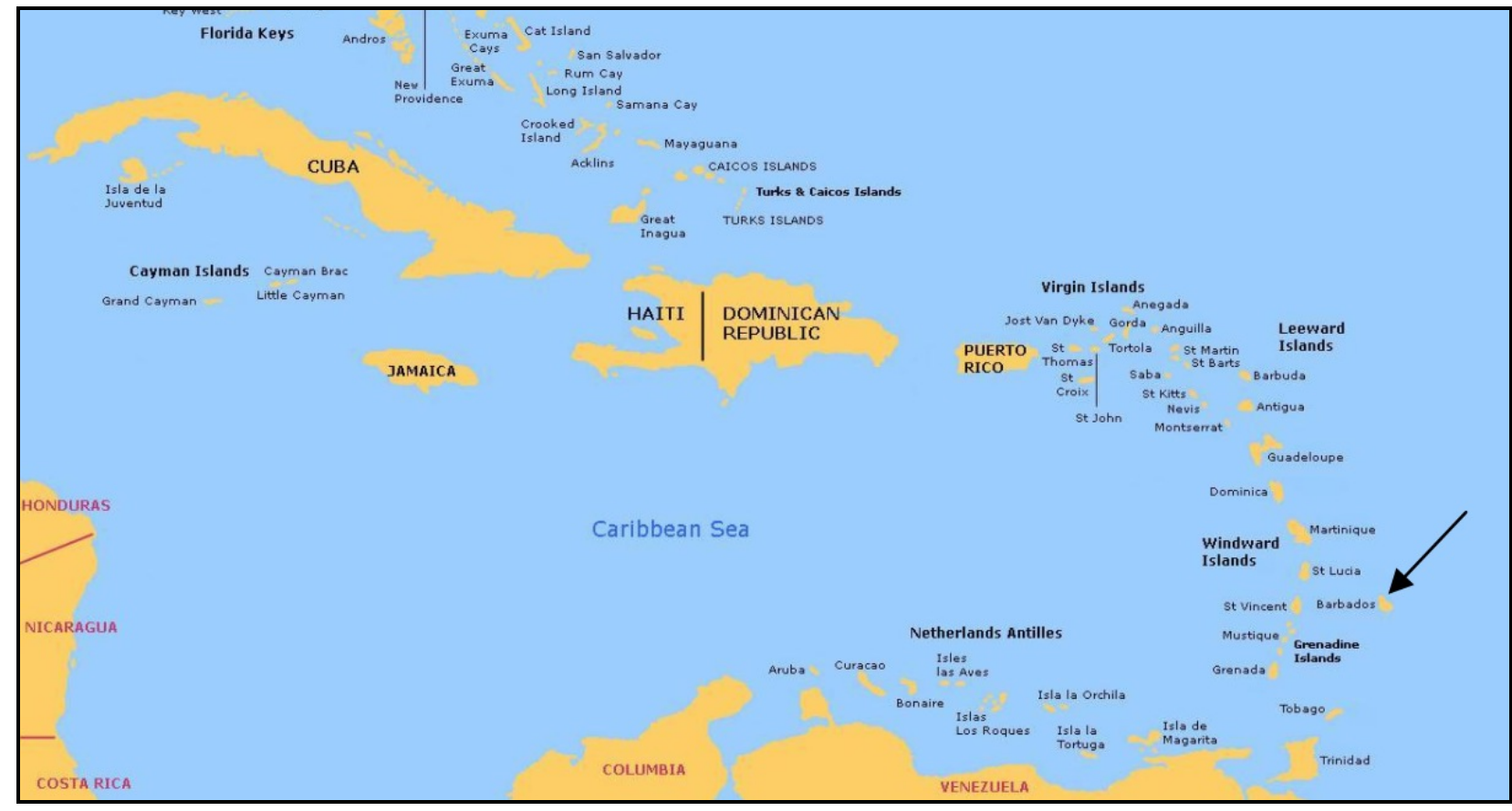

Figure 2. Location of Barbados in the Caribbean.

\section{Solar PV and Barbados}

Barbados's primary energy sources are petroleum products (see Figure 3). It does have local oil and gas reserves (around 1000 barrels per day) but no refining capabilities, and relies heavily upon imported petroleum products (around 8000 barrels per day) (US DoE, 2010). Electricity generation $(\sim 50 \%)$ and transport $(33 \%)$ are by far the two largest consumers of the fuel imported onto the island. The manufacturing sector is a distant third at $\sim 5 \%$.

Of the electricity generated ( $~ 885$ million kilowatt hours in 2005), domestic consumption was the major user at 34\%. The commercial sector was the second largest consumer with $23 \%$. The public sector and the hotel sector both consumed 15\% of the electricity generated in 2004 
(see Figure 4). In 2009, the total electricity generated was 952.2 million $\mathrm{kWh}$ with a peak demand of 165.7 MW. The price of the fuel imported for electricity generation was around US\$220 million (BL\&P, 2010).

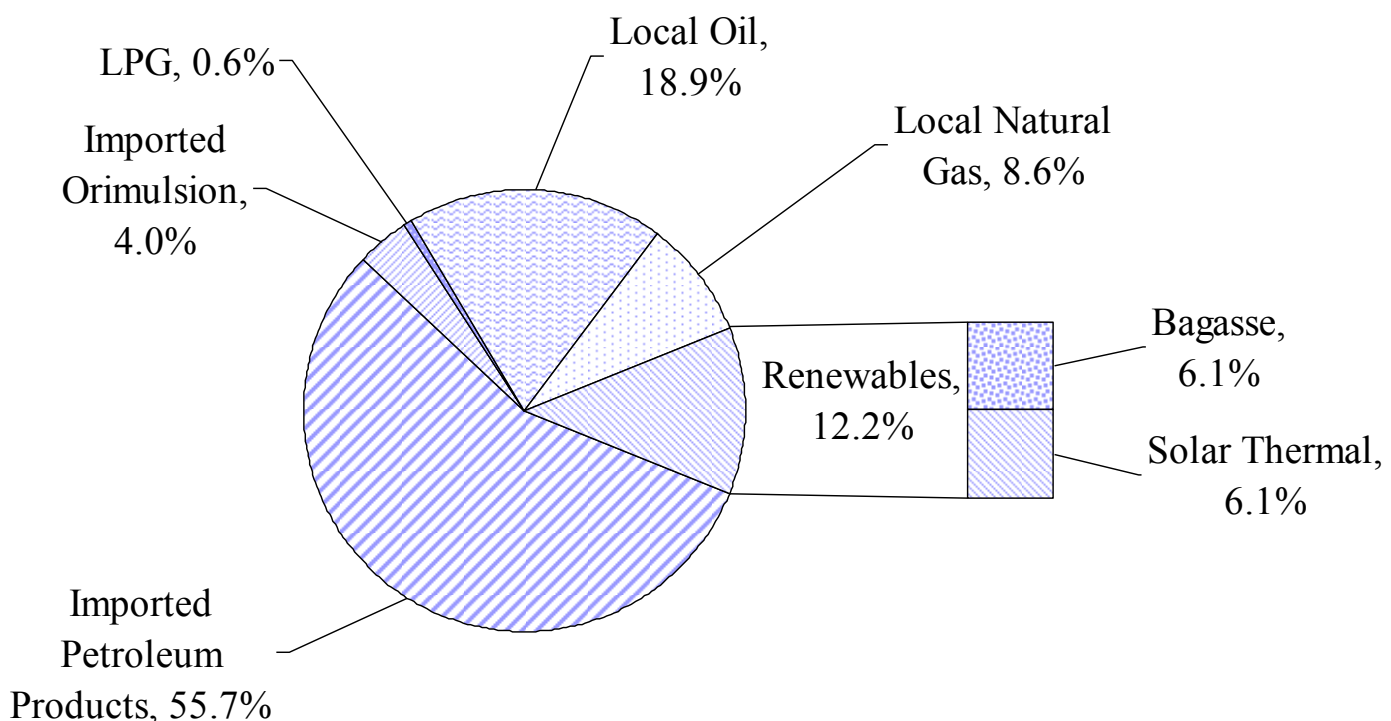

Figure 3: Primary energy mix, 1999.

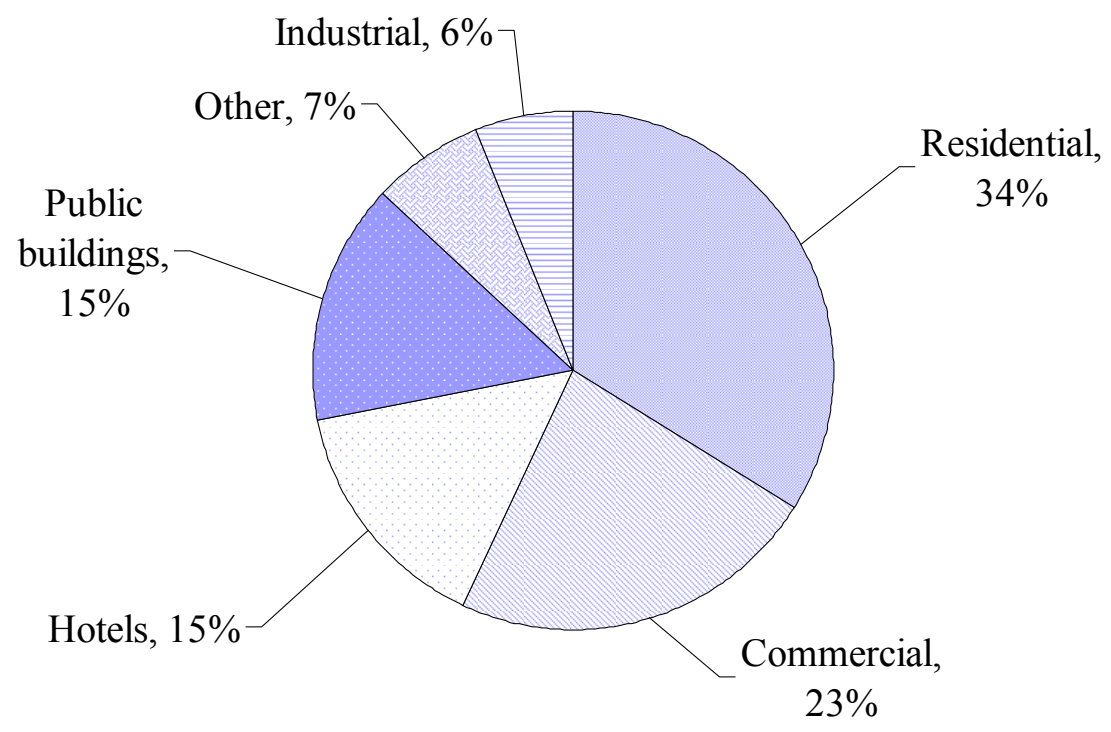

Figure 4. Electrical energy use by sector, 2004. Total sales that year, 831.3 GWh [7]

Barbados has a target for renewable energy to account for $30 \%$ of island's primary energy by 2012 . Though the electricity generation is close to $100 \%$ fuel-based, $15 \%$ of island's primary energy supply is currently from solar hot water systems and bagasse (Barbados National Energy Policy DRAFT, 2007). 
PV systems have been used in the Caribbean for many years, especially for telecommunications to power microwave repeater stations and navigational aids in remote areas (Wellington and Moore, 2001). It is estimated that there is currently around $200 \mathrm{kWp}$ of PV installed on Barbados with roughly 55\% installed in the commercial sector, $31 \%$ in the public sector and $14 \%$ in the residential sector (see Figure 5). This data was collected by contacting PV installers and government officials on the island.

In 2001 BL\&P installed two grid-connected PV systems, one at their Seawell operations plant and the other at the Barbados Future Centre. Both systems have been operating consistently since their installation with the $2 \mathrm{kWp}$ system at Seawell providing an annual energy yield of around 4.2 MWh, a load factor of $23 \%$ (for comparison, typical load factors for solar PV elsewhere in the world are normally quoted between $8-15 \%$ ).

Following the peak oil prices in the mid 2000s and the subsequent increase in electricity bills on the island, some residents who could afford to do so installed their own stand-alone PV systems on their properties. It is estimated that around $26 \mathrm{kWp}$ of PV has been installed on residential roofs ( $\sim 20$ homes), either with battery storage or for swimming pool water pumping.

Notable commercial installations include a $60 \mathrm{kWp}$ system at Harrison's Caves (which will eventually power the lighting and electric passenger vehicles for a vast network of limestone caves), and a $50 \mathrm{kWp}$ system that is currently nearly completion at the Barbados National Oil Company's main site offices.

Additionally, the Government of Barbados has installed around $50 \mathrm{kWp}$ of PV on its buildings and continues to install with a system currently under construction on the Ministry of Transport and Works building in St Michael.

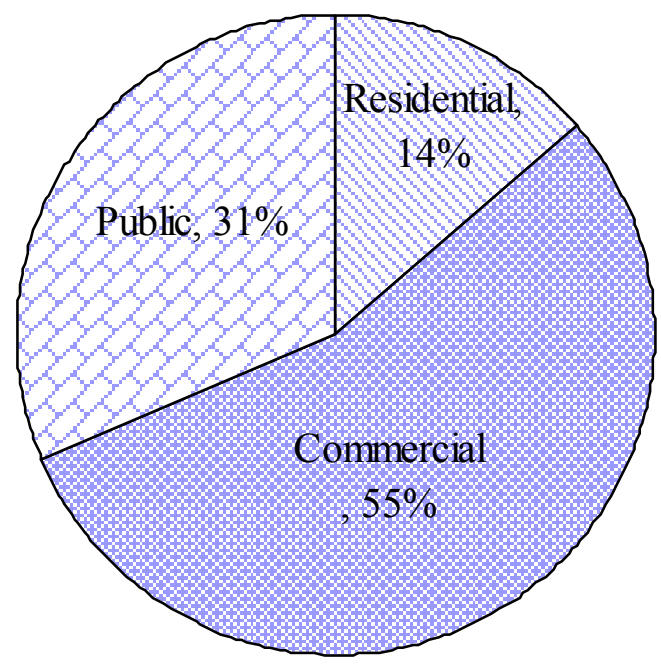

Figure 5. Current PV installations on Barbados by sector.

Until recently, except for the two PV systems installed by BL\&P, all PV systems on the island have been stand alone. It was not permitted to connect to the grid and sell excess electricity by this means. This however changed in July 2010 under a pilot project instigated by the Barbados Fair Trading Commission and being undertaken by BL\&P for a period of two years (FTC, 2010). Known as the Renewable Energy Rider (RER), it is available on a first-come firstserved basis up to a maximum of 200 eligible electricity customers or a combined installed capacity of 1.6 MW, whichever occurs first. The rider is aimed specifically at PV and small-scale 
wind. Seen as a precursor to a national feed-in tariff, customers will receive 1.8 times the fuel adjustment clause (at current rates this would be $20.91 \mathrm{US} \phi / \mathrm{kWh}$ ) or $15.56 \mathrm{US} \phi / \mathrm{kWh}$, whichever is greater. This is seen as a reasonable price for a country as small as Barbados although to put this into context, France, Greece, Germany, UK, all have feed-in tariffs for PV of more than 50 US $\notin / \mathrm{kWh}$. Also, in the first instance the tariff will only be in effect for the two year duration of the RER, given that the island has committed to a $10 \%$ of electricity generation coming from renewables by $2012(\sim 12 \mathrm{MW})$, some feel that the limit of $1.6 \mathrm{MW}$ is too cautious (considering that the actual energy input will be a fraction of this amount taking into account a typical load factor of around 0.2 for the island).

Barbados has a history of electrical manufacturing industries and in 2001 the case was put forward to make the island the PV module supplier the Caribbean region, and select South American countries. A business plan sent to the Caribbean Business Enterprise Trust (CBET) outlines establishing and operating a 1-3 MW/year crystalline silicon photovoltaic module assembly plant in Barbados (Headley, 2001). However this did not progress beyond the feasibility study and it is now felt that competition from PV module manufacturers elsewhere in the world (China, Europe and the US) make the idea redundant.

Besides the Renewable Energy Rider, other financial incentives do exist. All goods entering Barbados are subject to four kinds of import tax: Import Duty (0-20\%); Environmental Levy (1\%); Excise Tax (only for vehicles, tobacco products, alcoholic Beverages and petroleum products); Value Added Tax (15\%). In 2006, the import duty and environmental levy for PV systems (originally 20\%) was waived. This covers the main components such as the panels and inverters. However value added tax is still enforced.

Homeowners are also able to claim back the income tax on the money invested on their systems. A US\$2500 Income Tax Reduction is applicable for five consecutive years, amounting to US\$12,500 in tax deductions. This can be combined with the US\$5,000 Income Tax Home Improvement Scheme. Similar reductions are available to businesses corporation tax payments. The standard rate of corporation tax is currently $25 \%$.

\section{Barriers}

The most significant barriers to the development of renewable energy technologies on small islands are financial, institutional, and political. Financial barriers involve the fact that the purchase of renewable energy technologies is often associated with high initial investment costs. Most islands with a large renewable energy capacity are not sovereign and being politically connected to the mainland, get substantial economic support in all sectors. Typically, small island developing states do not have similar support and often have to rely on international bilateral and multilateral agreements to help provide investment (Jensen, 1998.). Political will needs to be the main driver for the policy implementation and development, as well as the main source for providing fiscal and economic support for sustainable development.

The main barriers for PV development are similar to those mentioned above; financial and economic barriers, lack of technological awareness, higher operational costs of new technologies, policy-related barriers and a lack of training and research (FTC, 2010). An example of lack of technological awareness was found when investigating the potential of solar PV for hotels on Barbados (Rogers et al, 2010). A number of hotel owners admitted to not realising that solar PV is used to convert solar energy directly into electrical energy. This misconception could be due to the success of solar hot water panels on the island but it does highlight a low level of information distribution on renewable energy options. 


\section{Conclusions}

It is crucial for small island developing states to improve access to renewable energy sources as this will enable them to increase energy security, reduce energy poverty, develop sustainably as well as help in the worldwide effort to mitigate the impact of climate change.

In order to further promote PV development on the island, the government should develop policies that define the sectors to which solar PV can be widely applied (for example, the hotel sector), develop financial incentives for potential PV users and those with lower income, encourage adequate training of local people to promote technical awareness, and provide financial support for R\&D (ECLAC, 2009).

Although Barbados is making progress with respect to renewable energy development as well as energy efficiency and energy conservation, the island as with other SIDS, must move aggressively to take advantage of sustainable energy sources as they become more accessible and affordable.

\section{References}

Barbados National Energy Policy DRAFT. 2007. Available at http://www.bajanpower.com (accessed 24 April 2010)

BL\&P annual report. May 2010. Available at http://www.blpc.com.bb/photos/BLP\%20REPORT.pdf (accessed 24 September 2010)

EIA, DoE Statistics (Available at http://www.eia.doe.gov/country/) (accessed 24 September 2010)

FTC, Barbados. http://www.ftc.gov.bb/ (accessed 24 September 2010)

Garcia, A. and Meisen, P., 2008. Renewable Energy potential of small State Islands. Global Energy Network Institute.

Headley, O. 2001. Barbados Photovoltaic Module Assembly Plant Five-Year Business Plan. Available at: http://www.cbetmodel.org/documents/PV-Module-Executive-Summary.pdf (accessed 24 September 2010)

Headley, O. 1998. Solar Thermal Applications in the West Indies. Renewable Energy Vol 15. pp. 257-263.

Jensen, T.L., 1998. Renewable energy on small islands. Available from http://www.geni.org/globalenergy/library/technical-articles/generation/small-islandnations/renewable-energy-on-small-islands/index.shtml (accessed 24 September 2010).

Langniß, O. Ince, D. 2004. Solar Water Heating - A Viable Industry for Developing Countries. Refocus. Vol May/June 2004. pp. 18-21.

Moseley, L. Headley, O. 1999 Medium scale photovoltaic applications for Barbados. Renewable Energy. Vol 17. pp. 1-7.

Science and Technology. Solar Technology and Sustainable Development: Building on the Solar Dynamic Experience. Volume 2. Small Island Developing States. Section 2.4 - 15, pp. 175183. Available at: http://ssc.undp.org/uploads/media/Solar technology.pdf (accessed 24 September 2010)

Rogers, T. Chmutina, K, Moseley, L. The potential of PV installations for the island of Barbados. 9th International Conference on Sustainable Energy Technologies. 24-27 August, 2010.

UNDP Human Development Report. Available at: http://hdr.undp.org/en/statistics (accessed 24 September 2010) 
UN Economic and Social ENV/DEV/893, 2006. Renewable energy essential for well-being of small island developing states. Available at:

http://www.geni.org/globalenergy/library/technical-articles/generation/small-islandnations/renewable-energy-essential-for-well-being/index.shtml (accessed 24 September 2010).

Wellington, C. Moore, R. 2001. Barbados' First National Communications to the UNIPCC. Ministry of Physical development Environment, Barbados.

\begin{abstract}
About the authors
Tom Rogers is a lecturer in Renewable Energy at the Department of Computer Science, Maths and Physics, University of the West Indies, Barbados. He is the corresponding author and can be contacted at thomas.rogers@cavehill.uwi.edu.

Ksenia Chmutina is a research associate at the Department of Civil and Building Engineering, University of Loughborough, UK. She is currently working on the CLUES project, Challenging Lock-in in Urban Energy Systems.

Leo Moseley is a Professor Emeritus at the Department of Computer Science, Maths and Physics, University of the West Indies, Barbados.
\end{abstract}

